\title{
Toxic Effects of Administration of Cypermethrin, Vitamin E, Zinc and Their Mixtures on the Hormonal Levels of Thyroid, Kidney Functions and some Biochemical Parameters in Male Mice
}

\author{
Heba M. El-Danasoury ${ }^{1}$; Alaa M. Khozimy ${ }^{2}$; Laila A. Reda ${ }^{1}$ and Marwa S. Kamel ${ }^{1}$ \\ ${ }^{1}$ Suez canal University, Faculty of Agriculture, Plant Protection Department, Ismailia, Egypt \\ ${ }^{2}$ Damanhour University, Faculty of Agriculture, Plant Protection Department, Damanhour, Egypt
}

Received: $21 / 11 / 2020$

\begin{abstract}
The present study investigates the effects of cypermethrin (CYP) on thyroid gland function, serum lipogram, kidney function, some liver enzymes and brain acetylcholinestrase (AchE) activity in male mice. Cypermethrin was administrated orally to mice at $9 \mathrm{mg} / \mathrm{kg} \mathrm{b}$.wt/day for 4 weeks (Dose period) followed by 2 weeks of ceasing treatments (recovery period). Male mice were randomly divided into five groups of eight each: a control (untreated check group) (1), CYP-treated group (2), CYP (9 mg/kg/day) +vitamin E (18 mg/kg/day) (3), CYP + zinc ( $20 \mathrm{mg} / \mathrm{kg} / \mathrm{day})$ (4) and $\mathrm{CYP}+\mathrm{E}+z i n c(5)$. Results revealed that triiodothyronine (T3) and thyroxine (T4) were significantly decreased in CYPgroup compared to control. In addition, the thyroid stimulating hormone (TSH) was also affected and recorded a significant increase by the treatments of CYP alone and CYP+vit E during the administration period. Also, significant increases of some biochemical parameters of kidney function (uric acid and creatinine) in serum were observed in CYPgroup compared to control. The administration of zinc with CYP group (4) improved all parameters studied (uric acid, creatinine, T3, T4 and TSH) as compared with control. The level of total lipid was significantly decreased, while triglycerides, total cholesterol and HDL-cholesterol were significantly increased by cypermethrin administration. The activity of liver and serum gamma glutamyl transferase (GGT) were significantly increased after CYP administration, while the results showed marked reduction of liver glutathione (GSH) concentration and the activity of glutathione-stransferase (GST). After cypermethrin administration with vitamin E, the activities of GGT, GST, and GSH level were significantly decreased compared to control. Moreover, inhibition percentage of brain acetylcholinestrase (AchE) activity was $62.98 \%$ by cypermethrin alone, but other groups (3), (4) and (5) had no effect on brain AchE activity. Results demonstrated the beneficial influence of vitamin $\mathrm{E}$ and zinc addition in combinations to reduce the harmful effects of cypermethrin.
\end{abstract}

Keywords: Cypermethrin, Vit E, Zinc, Thyroid hormones, Kidney functions, some biochemical parameters, male mice

\section{INTRODUCTION}

Pyrethroid pesticides are a group of man-made chemical products which are widely used in and around households as well as in agriculture. The use of pyrethroids has been increased during the past decade with the declining use of organophosphate pesticides, which are more acutely toxic to birds and mammals than pyrethroids (Bateman, 2000; Shafer et al., 2004).

Cypermethrin is a synthetic pyrethroid which is highly used pesticide in agriculture, household and animal husbandry mainly to crack, crevice and spot treatment for insect control. Cypermethrin targets sodium channel along with magnesium and Apse in human body and animals. Cypermethrin is primarily mediated through hyper-excitation of the central nervous system. Additionally, cypermethrin induces neurotoxicity by modulating the level of gammaamino butyric acid (GABA). Furthermore, cypermethrin mediated neurotoxicity is contributed by its ability to induce free radical generation (Aman et $a l ., 2018$ ). Cypermethrin has been extensively used in the developing countries, for combating agricultural pests and insects of veterinary as well as human concern (Assayed et al., 2010a). The synthetic pyrethroid insecticides are widely applied in view of the fact that they have shown to possess a high insecticidal activity as well as a broad spectrum of high initial toxic action on several types of pest (Assayed et al., 2010b).
Zinc can be found in normal biological processes, including genetic expression, DNA synthesis, enzymatic catalysis, neurotransmission and apoptosis (Gumulee et al., 2011). Zinc is a dismutase superoxide cofactor, showing the chelating ability, thus stabilizing cell membranes, inhibiting lipid peroxidation and inducing metallothionein synthesis (Prasad, 2008). Zinc (Zn) as an essential trace element is necessary for animals. Zinc has been reported to have protective role in reducing the damage due to increase oxidative damage (Kang and Zhou, 2005). Zn is effective in stabilizing the cell membrane and prevents its oxidative destruction caused by free radicals. The antioxidant effect of $\mathrm{Zn}$ is mediated through the induction of metallothionein, which is a potent scavenger of toxic metals and hydroxyl radical (Kazi et al., 2012).

Vitamin $\mathrm{E}$ is an important antioxidant in biological systems (Nazirogln et al., 1999). Many authors studied the protective effects of vitamin $\mathrm{E}$ on the toxicant-induced organ damage in mammals (ElSayed, 2001). Vitamin E in the mice plays an important role as a part of multicomponent antioxidant defense system. This system protects the cell against the adverse effects of reactive oxygen and other free radical initiators of the oxidation of polyunsaturated membrane phospholipids, critical proteins or both (Herman and Ferrans, 1983). Administration of vitamin $\mathrm{E}$ and selenium was reported to be useful in 
controlling cypermethrin induced oxidative stress in rats (Atessahin et al., 2005).

Some experimental studies have shown that vitamins $\mathrm{C}$ and $\mathrm{E}$ can be used to counteract pesticide toxicity (Yavuz et al., 2004; Yousef et al., 2006). Several biological defense mechanisms against intracellular oxidative stress are present in the organism such as antioxidant enzymes (glutathione reductase and glutathione-s-transferase) and nonenzymatic antioxidants such as vit $\mathrm{E}$, vit $\mathrm{C}$ and glutathione which can also act to overcome the oxidative stress of the pesticides (Evans and Halliwell, 2001). Vitamin $\mathrm{E}$ ( $\alpha$ - tocopherol) is a fat -soluble antioxidant in cells and protect cellular membranes and lipoproteins from peroxidation. In addition, several studies have indicated that vitamin $\mathrm{E}$ has an effective role in inhibiting the free radical formation and so reduce lipid peroxidation in biological systems (Uzun et al., 2009). The previous study had shown that vitamin $\mathrm{E}$ deficiency can lead to infertility due to its polyphenol components rapidly generates free radicals and protect rat tissues (Jalili et al., 2014). Vitamin E protects critical cellular structures against damage caused by oxygen-free radicals and reactive products of lipid peroxidation (Yousef, 2010).

Therefore, the present study was carried out to investigate the toxicity induced by cypermethrin alone and with vitamin $\mathrm{E}$, with zinc and their combination by oral administration after 4 weeks. Thus, the present investigation aims to explore some physiological and biochemical changes in the levels of serum lipid profile, the thyroid hormones and antioxidant defense system under the influence of cypermethrin alone or mixed with vitamin $\mathrm{E}$ and zinc.

\section{Chemicals \\ MATERIALS AND METHODS}

-Cypermethrin $( \pm)$ cynao-3- phenoxybenzyl- $( \pm)$ cis, trans-3-(2,2-dichlorovinyl)-2,2, dimethyl cyclopropane carboxylate (98\%) [Philadelphia, PA, USA](CYP).

-Zinc chloride $\left(\mathrm{ZnCl}_{2}\right)$ powder $(98 \%$ purity) was obtained from El-Gomhoria Co., Egypt (ZN).

-Vitamin E (DL-tocopheral acetate) used in this study on a protective agent was purchased from Pharco Pharmaceuticals, Alexandria, Egypt (Vit E). It was dissolved in corn oil with daily dose of $18 \mathrm{mg} / \mathrm{kg}$ mouse body weight as recommended by Saeed and ElGendy (2000).

\section{Animals}

Eighty adult albino male mice (Mus musculus) (40-45 g) used in this experiment were obtained from the animal house of the Institute of Graduate Studies and Research, Alexandria Univ., Egypt. Animals were acclimatized to the laboratory condition for four weeks before being used. Animals were fed ad libitum with standard laboratory diet and allowed free access of water. All animals were maintained on a $12 \mathrm{hr}$ light/12 hr dark cycle at constant temperature $(25 \pm$ $\left.1^{\circ} \mathrm{C}\right)$.

\section{Experimental design}

The mice were divided randomly into five groups each of sixteen; eight of them were used for recovery period ( 2 weeks). The oral administration was daily done for 4 weeks and the followed protocol was as that seen in Table (1).

Table (1): Experimental mice groups and their protocol of treatments administration

\begin{tabular}{cll}
\hline Group No. & Groups administrated with & \multicolumn{1}{c}{ Dose } \\
\hline $\mathbf{1}$ & $\mathbf{2 5 0} \boldsymbol{\mu l}$ corn oil $/$ mice & $($ Control $)$ \\
$\mathbf{2}$ & $\mathbf{C Y P}$ & $9 \mathrm{mg} / \mathrm{kg}$ body weight $/ \mathrm{day}$ \\
$\mathbf{3}$ & $\mathbf{C Y P}+$ vit. $\mathbf{E}$ & $9 \mathrm{mg} / \mathrm{kg} / \mathrm{day}+\mathrm{vitamin} \mathrm{E}(18 \mathrm{mg} / \mathrm{kg} / \mathrm{day})$ \\
$\mathbf{4}$ & $\mathbf{C Y P}+$ Zinc & $9 \mathrm{mg} / \mathrm{kg} / \mathrm{day}+\mathrm{ZnCl} 2(20 \mathrm{mg} / \mathrm{kg} / \mathrm{day})$ \\
$\mathbf{5}$ & $\mathbf{C Y P}+$ vit. $\mathbf{E}+$ Zinc & $9 \mathrm{mg} \mathrm{CYP}+18 \mathrm{mg}$ vitamin E $+\mathrm{ZnCl} 2(20 \mathrm{mg} / \mathrm{kg} / \mathrm{day})$ \\
\hline
\end{tabular}

Cypermethrin $=\mathrm{CYP} \quad \mathrm{n}=8$

Mice of all groups were orally administered with suggested doses of the running treatments for four weeks (experimental period). The treatments were ceased after that for two weeks (recovery period).

Mice were then scarified at the end of experimental and recovery periods. Blood samples were collected in clean dry test tubes, serum were separated by centrifugation at $4000 \mathrm{rpm}$ for 20 minutes at $4{ }^{\circ} \mathrm{C}$ and stored at $-20^{\circ} \mathrm{C}$ pending analysis.

\section{The determination of the evaluated parameters}

\section{Hormonal assay}

Serum levels of thyroxine $\left(\mathrm{T}_{4}\right)$, Triiodothyronine $\left(\mathrm{T}_{3}\right)$ and Thyroid stimulating hormone (TSH) were determined by using enzymelinked immunosorbent assays (ELISA) diagnostic kits obtained from Sigma Chemical Co., and have been done according to the method of Thakur et al. (1997) for thyroxine $\left(\mathrm{T}_{4}\right)$, Triiodothyronine $\left(\mathrm{T}_{3}\right)$, Morimoto and Inouye (1997) for Thyroid stimulating hormone (TSH).

\section{Serum lipid profile}

Serum total cholesterol and triglycerides were estimated by using diagnostic kit No.351 and 336, respectively obtained from Sigma Chemical Co., and have been done according to the methods of Allian et al. (1974), Fossati and Prencipe (1982), respectively. Levels of total lipids were determined according to the 
method of Knight et al. (1972). Low density lipoprotein cholesterol (LDL-Cholestrol) and high density lipoprotein cholesterol (HDL-Cholestrol) were determined using Boehringer Mannheim kits (Germany) according to the methods of Freindewals et al. (1972), Burstein (1970), respectively.

\section{Uric acid and creatinine measurements}

Kits of uric acid and creatinine produced by Medical device safety services MDSS GmbH Burckhardts Tr 1 Hannover, Germany were obtained from Vitro Scient, Heliopolis, Cairo, Egypt, and the measurements were carried out according to the methods of Morgenstern et al. (1966), Mitchell (1973), respectively.

\section{Determination of Glutathione-s-transferase (GST)}

Each the control and treated livers of mice were weighted and homogenized in five volume (i.e. $5 \mathrm{ml} / \mathrm{g}$ wet tissue) of $0.1 \mathrm{M}$ sodium phosphate buffer $(\mathrm{pH} 7.5)$ in a homogenizer. The homogenate was centrifuge for $60 \mathrm{~min}$ at $20000 \mathrm{rpm}$ at $4^{\circ} \mathrm{C}$ using Ultra centrifuge Glutathione-s-transferase (GST, EC 2.5.1.18) activity as described by Habig et al. (1974), using pnitrobenzyl chloride as a substrate protein concentration and the enzyme was assayed following the method of Lowry et al. (1951). Gamma-glutamyl transferase (GGT) activity in liver was estimated according to the method of Young (1990).

Determination of Glutathione (GSH) concentration

The method used for the determination of (GSH) was essentially as same as that described by Richardson and Murphy (1975) with minor modifications. The liver tissue was homogenized in $10 \%$ perchloric acid and then centrifuged 3000rpm for $15 \mathrm{~min}$ in an Eppendorf centrifuge.GSH quantity was determined in the supernatant and protein quantity was determined in the precipitate. The GSH assay mixture contained 5.5-dithiobis-2-nitrobenzoic acid, DTNB $(0.5 \mathrm{mM})$ dissolved in sodium phosphate buffer ( $\mathrm{pH} 8,0.1 \mathrm{M})$ and supernatant $(10-20 \mu \mathrm{l})$. The mixture was incubated for $10 \mathrm{~min}$ at room temperature before the absorbance was read at the wave length of $412 \mathrm{~nm}$. Protein in precipitate were redissolved in sodium hydroxide $(1 \mathrm{M})$ for $2 \mathrm{~h}$ in a shaking water bath at $46^{\circ} \mathrm{C}$ and their quantity was determined by the method of Lowry et al. (1951).

\section{Determination of acetylcholinestrase (AchE)}

The brains of control and treated mice were weighted and homogenized in ten volumes (i.e. 10 $\mathrm{ml} / \mathrm{g}$ wet tissue) of cool $0.1 \mathrm{M}$ phosphate buffer $\mathrm{pH} 8$, using homogenizer for 50 seconds. The homogenate was then centrifuged at $8000 \mathrm{rpm}$ for $20 \mathrm{~min}$ at $4^{\circ} \mathrm{C}$ using Ultra-Centrifuge.

The supernatant was collected as the enzyme source for AchE and AchE activity was assayed by the method of Ellman et al. (1961) using acetylthiocholine iodide as a substrate. Protein content was assayed using bovine serum albumin as a standard.

\section{Statistical analysis}

Results are presented as mean \pm standard error (S.E). Statistical analysis of the results was done according to the student -t-test (Hine and Wetherill, 1975) to find the differences between treated and control animals.

The percentage of change of each parameter from the corresponding control value was also calculated as the following formula:

$\%$ of change $=[$ treatment - control $/$ control $\times 100$

\section{RESULTS AND DISCUSSION}

Cypermethrin a pyrethroid pesticide is widely used in developing countries for pest control in agriculture, home and garden either alone or in combination with other pesticides (Jee et al., 2005; Sangha et al., 2013). The toxic effects of administration of cypermethrin, vitamin E, zinc and their mixtures on the hormonal levels of thyroid, kidney functions and some biochemical parameters in male mice were evaluated.

Effect of oral administration of cypermethrin alone, with vitamin $\mathrm{E}$, with Zinc and their mixture on serum Triiodothyronine $\left(\mathrm{T}_{3}\right)$, tetraiodothyronine - thyroxin $\left(\mathrm{T}_{4}\right)$ and thyroid stimulating hormone (TSH) activity in male mice

Table (2) is showing the effects of cypermethrin alone (CYP), with vit. E (CYP+vit.E), with zinc $(\mathrm{CYP}+\mathrm{Zn})$ and their combination $(\mathrm{CYP}+$ vit. $\mathrm{E}+$ zinc) on the activity of $\mathrm{T}_{3}, \mathrm{~T}_{4}$ and $\mathrm{TSH}$. Dosages were administrated daily for four weeks period and then the administration was ceased for two weeks as a recovery period. All the evaluated parameters were measured after the administration period and after the recovery period. Serum levels of $T_{3}$ and $T_{4}$ were significantly lower when cypermethrin alone was orally administrated ( $9 \mathrm{mg} / \mathrm{kg}$. bwt/day) to mice showing change percentage of $-31.91 \%$ and $-47.45 \%$, respectively as compared with control. On contrary, TSH was highly significant increased with the administration of cypermethrin alone $(87.50 \%)$ and with vitamin E (91.66\%), while group 4 (CYP+zinc) and group $5(\mathrm{CYP}+$ vit. $\mathrm{E}+$ zinc) gave more or less the same values of TSH activity as that of control. These findings are in agreement with the data obtained by Girgis et al. (2000) who recorded an increase in TSH level accompanied by a decrease in $\mathrm{T}_{3}$ and $\mathrm{T}_{4}$ levels in rats.

The presented results are in accordance with those reported by Wang et al. (2002) and Finch et al. (2006) who found a decrease of both $T_{3}$ and $T_{4}$ and increase of TSH activity in the serum of the experimental rats exposed to different synthetic pyrethroid compounds. 
Table (2): Effect of oral administration of cypermethrin alone, with vitamin E, with Zinc and their mixture on hormonal levels of thyroid gland $\left(\mathrm{T}_{3}, \mathrm{~T}_{4}\right.$ and $\left.\mathrm{TSH}\right)$ in male mice after 4 weeks (dosage period) and recovery period (2 weeks after ceasing the administration)

Triiodothyronine $\left(\mathbf{T}_{3}\right) \mathbf{n g} / \mathrm{dl}$

\begin{tabular}{|c|c|c|c|c|}
\hline \multirow{2}{*}{ Groups administrated with } & \\
\hline & Dose period & (\%) change & Recovery period & (\%) change \\
\hline Control & $103.2 \pm 1.93$ & - & $103.2 \pm 1.93$ & - \\
\hline CYP & $70.30 \pm 1.20 *$ & -31.91 & $88.25 \pm 1.30$ & -14.52 \\
\hline CYP+ vit. E & $90.25 \pm 1.27$ & -12.59 & $95.33 \pm 1.33$ & -07.67 \\
\hline CYP + Zinc & $110.3 \pm 1.42$ & +06.82 & $99.25 \pm 1.27$ & -03.87 \\
\hline \multirow[t]{2}{*}{ CYP+ vit. E+ Zinc } & $120.4 \pm 1.29$ & +16.61 & $100.3 \pm 1.20$ & -02.84 \\
\hline & \multicolumn{4}{|c|}{ Thyroxin $\left(T_{4}\right) u g / d l$} \\
\hline Control & $5.90 \pm 0.30$ & - & $5.90 \pm 0.03$ & - \\
\hline CYP & $3.10 \pm 0.45 *$ & -47.45 & $4.80 \pm 0.30$ & -18.64 \\
\hline CYP+ vit. E & $4.80 \pm 0.50$ & -18.64 & $4.99 \pm 0.28$ & -15.42 \\
\hline CYP + Zinc & $6.50 \pm 0.13$ & +10.16 & $5.10 \pm 0.33$ & -13.55 \\
\hline \multirow[t]{2}{*}{ CYP+ vit. E+ Zinc } & $7.10 \pm 0.25$ & +20.33 & $5.30 \pm 0.35$ & -10.16 \\
\hline & \multicolumn{4}{|c|}{ TSH uU/ml } \\
\hline Control & $0.48 \pm 0.03$ & - & $0.48 \pm 0.03$ & - \\
\hline CYP & $0.90 \pm 0.09 * *$ & +87.5 & $0.40 \pm 0.02$ & -16.66 \\
\hline CYP+ vit. E & $0.92 \pm 0.08 * *$ & +91.66 & $0.46 \pm 0.01$ & -04.16 \\
\hline CYP + Zinc & $0.50 \pm 0.09$ & +04.16 & $0.47 \pm 0.02$ & -02.00 \\
\hline CYP+ vit. E+ Zinc & $0.49 \pm 0.05$ & +02.08 & $0.48 \pm 0.03$ & 00.00 \\
\hline
\end{tabular}

Each value is a mean $\pm \mathrm{SE} \quad$ where $\mathrm{n}=8$.

Statistical difference from the control: * =significant at $\mathrm{p} \leq 0.05, * *=$ highly significant at $\mathrm{p} \leq 0.001$.

$\%$ of change $=[$ treatment - control $/$ control $\times 100$.

\section{Biochemical studies}

\section{Changes in some components of lipid profile}

The present data in Table (3) indicated that serum total lipid was found to be decreased as a result of cypermethrin alone ( $9 \quad \mathrm{mg} / \mathrm{kg} \quad$ b.wt/day) administration after 4 weeks showing a change of $31.95 \%$ (less than control). On the other hand, the alterations induced in serum total lipid by cypermethrin with vit E, CYP with zinc and their combination appeared to be elevated giving higher percentages of $+27.44 \%,+25.28 \%$ and $+35.99 \%$ more than that of control animals, respectively. However, after the recovery period, the level of total lipid in all groups revealed a tendency to return to normal control values.

It has long been known thyroid hormones affect synthesis, mobilization and degradation of lipids with degradation being more influenced than synthesis as was reported by Pucci et al. (2000) and Asami et al. (2001). The hypolipidaemia was probably a result of mobilizing and degradation of lipids and increased accumulation of liver total lipids as was suggested by Abdel-Raheem et al. (1995).

The results in Table (3) indicated the effect of cypermethrin (9 $\mathrm{mg} / \mathrm{kg}$ b.wt/day) on the serum triglycerides content where it was found to be increased $(+82.05 \%)$ after 4 weeks of oral administration, following by an insignificant change by the treatment of cypermethrin with vit. E, but when zinc was supplemented with cypermethrin (group 4) there was no any significant effect compared to the corresponding control, showing the same results as that of control animals. Considering the effect of cypermethrin alone on the serum total cholesterol, it was found that their level significantly increased after 4 weeks of administration. Ghazouani et al. (2020) reported that $\alpha$-cypermethrin (CYP) is a pyrethroid insecticide-like environmental pollutant, widely found in the environment. In addition, CYP was administrated at a dose of $8 \mathrm{mg} / \mathrm{kg}$ b.wt for 8 weeks by male Wistar rats. CYP caused a significant increase of $42 \%$ of that the concentration of the total cholesterol and more than $75 \%$ in triglycerides as compared to the control group.

Abdel-Razik (2018) evaluated the biochemical alteration associated with Imidacloprid (IMC) toxicity in male albino mice. The animals were orally administrated with (IMC) at a rate of $2.6 \mathrm{mg} / \mathrm{kg}$ b.wt/day for 28 days. The results showed that Imidacloprid administration caused a significant increase of total cholesterol, triglycerides and high density lipoprotein cholesterol (HDL-cholestrol).

\section{The effect of tested treatments on kidney functions parameters}

To study the effect of cypermethrin alone, with vit. E, with zinc supplementation and CYP + vit. E + zinc on kidney function, the concentration of uric acid and creatinine were determined after 4 weeks of administration (dosage period) and also they were determined after 2 weeks of recovery period. 
Table (3): Effect of cypermethrin alone, with vitamin E, with zinc and their mixture on different types of lipid profile (total lipid, triglyceride, total cholesterol, HDL and LDL cholestrol) after 4 weeks (dosage period) and recovery period ( 2 weeks after ceasing the administration)

\begin{tabular}{|c|c|c|c|c|}
\hline \multirow{2}{*}{ Groups administrated with } & \multicolumn{4}{|c|}{ Total lipid mg/ dl } \\
\hline & Dose period & (\%) change & Recovery period & (\%) change \\
\hline Control & $1028.1 \pm 4.2$ & - & $1028.1 \pm 4.2$ & - \\
\hline CYP & $699.6 \pm 3.8^{*}$ & -31.95 & $888.5 \pm 3.2$ & -13.57 \\
\hline CYP+ vit. E & $1310.3 \pm 4.3$ & +27.44 & $920.8 \pm 3.1$ & -10.43 \\
\hline CYP + Zinc & $1288.1 \pm 3.9$ & +25.28 & $926.1 \pm 3.4$ & -09.92 \\
\hline \multirow[t]{2}{*}{ CYP+ vit. E+ Zinc } & $1398.2 \pm 4.3 *$ & +35.99 & $998.7 \pm 3.1$ & -02.85 \\
\hline & \multicolumn{4}{|c|}{ Triglycerides mg/dl } \\
\hline Control & $105.3 \pm 2.98$ & - & $105.3 \pm 2.98$ & - \\
\hline CYP & $191.7 \pm 2.80 * *$ & +82.05 & $99.01 \pm 2.2$ & -05.98 \\
\hline CYP+ vit E & $108.1 \pm 2.73$ & +02.65 & $100.7 \pm 2.8$ & -04.36 \\
\hline CYP + Zinc & $105.3 \pm 2.13$ & 00.00 & $106.5 \pm 2.5$ & +01.13 \\
\hline \multirow[t]{2}{*}{ CYP+ vit. E+ Zinc } & $110.7 \pm 2.80$ & +05.12 & $103.3 \pm 2.7$ & -01.89 \\
\hline & \multicolumn{4}{|c|}{ Total cholesterol $\mathrm{mg} / \mathrm{dl}$} \\
\hline Control & $81.5 \pm 1.2$ & - & $81.5 \pm 1.2$ & - \\
\hline CYP & $113.3 \pm 1.8 *$ & +39.01 & $91.3 \pm 1.1$ & +12.02 \\
\hline CYP+ vit. E & $100.5 \pm 1.7$ & +23.31 & $80.5 \pm 1.3$ & -01.22 \\
\hline CYP + Zinc & $90.3 \pm 1.3$ & +10.79 & $79.8 \pm 1.6$ & -02.08 \\
\hline \multirow[t]{2}{*}{ CYP+ vit. E+ Zinc } & $73.5 \pm 1.8$ & -09.81 & $77.9 \pm 1.3$ & -04.41 \\
\hline & \multicolumn{4}{|c|}{ HDL - Cholesterol mg/ dl } \\
\hline Control & $23.6 \pm 0.42$ & - & $23.6 \pm 0.42$ & - \\
\hline CYP & $35.7 \pm 0.40 * *$ & +51.27 & $25.01 \pm 0.39$ & +05.97 \\
\hline CYP+ Vit. E & $23.1 \pm 0.39$ & -02.11 & $23.5 \pm 0.41$ & -00.42 \\
\hline CYP + Zinc & $24.8 \pm 0.41$ & +05.08 & $23.8 \pm 0.40$ & +00.84 \\
\hline \multirow[t]{2}{*}{ CYP+ Vit. E+ Zinc } & $27.5 \pm 0.43$ & +16.52 & $23.5 \pm 0.42$ & -00.42 \\
\hline & \multicolumn{4}{|c|}{ LDL-Cholesterol $\mathrm{mg} / \mathrm{dl}$} \\
\hline Control & $33.4 \pm 1.25$ & - & $33.4 \pm 1.25$ & - \\
\hline CYP & $38.7 \pm 1.01$ & +15.86 & $35.01 \pm 1.27$ & +04.82 \\
\hline CYP+ vit. E & $33.8 \pm 1.17$ & +1.19 & $33.6 \pm 1.03$ & -00.59 \\
\hline CYP + Zinc & $34.01 \pm 1.21$ & +1.82 & $33.9 \pm 1.21$ & +01.49 \\
\hline CYP+ vit. E+ Zinc & $33.8 \pm 1.23$ & +1.19 & $33.4 \pm 1.21$ & 00.00 \\
\hline
\end{tabular}

Each Value is a mean $\pm \mathrm{SE} \quad$ where $\mathrm{n}=8$.

Statistical difference from the control: $*=$ significant at $\mathrm{p} \leq 0.05, * *=$ highly significant at $\mathrm{p} \leq 0.001$.

$\%$ of change $=[$ treatment - control $/$ control $\times 100$.

Effects of cypermethrin alone, with vit. E, with zinc and their combination on uric acid concentration

The data presented in Table (4) show that cypermethrin alone caused significant change (an increase of $+43.10 \%$ ) in the concentration of uric acid, while the supplementation of zinc with cypermethrin caused little alteration in percentage of change. Also, Table (4) showed that the percentage of change after 4 weeks administration of cypermethrin + vit. E + zinc did not cause significant effects compared to the corresponding control.

Effect of cypermethrin alone, with vit. E, with zinc and their combination on creatinine level in the male mice serum

Table (4) demonstrated that the administration of cypermethrin alone after 4 weeks gave the highest creatinine level that reached $0.98 \mathrm{mg} / \mathrm{dl}$, compared with the corresponding control value of $0.65 \mathrm{mg} / \mathrm{dl}$ and the other running treatments $(0.66-0.71 \mathrm{mg} / \mathrm{dl})$.

CYP showed a highly significant value that was more than that of control by $+50.76 \%$. However at the same period after 4 weeks all groups 3, 4 and 5 did not cause any significant change in the level of creatinine. The current study show that cypermethrin alone increased creatinine and uric acid concentrations in the serum of treated male mice and these results agreed with those of Eissa and Zidan (2010). Elevation of creatinine and uric acid concentration in serum of treated male albino rats may be attributed to reduction in glomerular filtration in the kidney and also reflect dysfunction of the kidney tubules (Walmsley and white, 1994). Creatinine and uric acid levels were used as biomarkers of kidney damages. Abdel-Razik (2018) evaluated the biochemical alteration associated with Imidacloprid (IMC) toxicity in male albino mice. Mice were orally administrated with) $2.6 \mathrm{mg}$ IMC / $\mathrm{kg}$ b.wt for 28 days. The result showed that both urea and creatinine were increased. El-Maghraby and Taha (2012) found that exposing rats to Deltamethrin (DLM) induced significant increase in urea and creatinine. They showed that vitamin E can act as an effective antioxidant for DLM pesticide toxicity by reducing oxidative stress burden. 
Table (4): Effect of cypermethrin alone, with vitamin E, with zinc and their mixture on kidney function through determination of uric acid and creatinine in serum of male mice after 4 weeks (Dosage period) and recovery period ( 2 weeks after ceasing the administration)

\begin{tabular}{llccc}
\hline \multirow{2}{*}{ Groups administrated with } & \multicolumn{4}{c}{ Uric acid mg/dl } \\
\cline { 2 - 5 } Control & Dose period & (\%) change & Recovery period & (\%) change \\
CYP & $5.80 \pm 0.48$ & - & $5.80 \pm 0.48$ & - \\
CYP+ vit. E & $8.30 \pm 0.46^{*}$ & +43.10 & $6.20 \pm 0.39$ & +6.89 \\
CYP + Zinc & $6.50 \pm 0.28$ & +12.06 & $6.30 \pm 0.46$ & +8.62 \\
CYP+ vit. E+ Zinc & $6.13 \pm 0.40$ & +5.68 & $6.09 \pm 0.47$ & +5.00 \\
\hline Control & $5.83 \pm 0.46$ & +0.51 & $5.79 \pm 0.46$ & -0.17 \\
CYP & & \multicolumn{4}{c}{ Creatinine $\mathbf{~ m g / d l}$} & - \\
CYP+ vit. E & $0.65 \pm 0.02$ & - & $0.65 \pm 0.02$ & +7.69 \\
CYP + Zinc & $0.98 \pm 0.01 * *$ & +50.76 & $0.70 \pm 0.03$ & +6.15 \\
CYP+ vit. E+ Zinc & $0.70 \pm 0.03$ & +7.69 & $0.69 \pm 0.01$ & +3.07 \\
\hline
\end{tabular}

Each Value is a mean \pm SE where $n=8$.

Statistical difference from the control: * =significant at $\mathrm{p} \leq 0.05, * *=$ highly significant at $\mathrm{p} \leq 0.001$.

$\%$ of change $=[$ treatment - control $/$ control $\times 100$.

Effects of cypermthrin, vit. E, zinc and their mixtures on liver and serum glutathione-Stransferase (GST), gamma glutamytransferase (GGT) and glutathione (GSH) level in male mice

Tables (5 and 6) show the effect of sub lethal dose of cypermethrin ( $9 \mathrm{mg} / \mathrm{kg}$ /day) alone, with vitamin E (18 mg/kg/day), with zinc $(20 \mathrm{mg} / \mathrm{kg} /$ day $)$ and their mixture (CYP+ vit E+ Zinc) as they were administrated for 4 weeks and ceased for 2 weeks (recovery period) on the detoxification system. The effect was assessed by determining glutathione (GSH) concentration, gamma-glutamyl transferase (GGT) and glutathione-S-transferase (GST) activities in animal's liver and serum. The results in Table (5) showed that both GST and GSH were significantly decreased (-36.80 and $20.92 \%$, respectively) in liver tissue as the animal were administrated with CYP alone, while gamma glutamyl transferase (GGT) was significantly increased $(+46.41 \%)$. The other running groups $3,4,5$ were did not cause any significant effect in the GSH concentration and GST and GGT activity.

Table (5): Effect of oral administration of Cypermethrin alone, with vitamin E, with zinc and their mixture on glutathione -s- transferase (GST), gamma glutamyl transferase (GGT) and glutathione (GSH) level in male mice liver

\begin{tabular}{|c|c|c|c|c|}
\hline \multirow{2}{*}{ Groups administrated with } & \multicolumn{4}{|c|}{ GST umole/mg protein /h } \\
\hline & Dose period & (\%) change & Recovery period & (\%) change \\
\hline $\begin{array}{l}\text { Control } \\
\text { CYP } \\
\text { CYP+ vit. E } \\
\text { CYP + Zinc } \\
\text { CYP+ vit. E+ Zinc } \\
\end{array}$ & $\begin{array}{l}9.51 \pm 0.43 \\
6.01 \pm 0.39 * \\
9.11 \pm 0.42 \\
9.01 \pm 0.38 \\
9.39 \pm 0.40 \\
\end{array}$ & $\begin{array}{r}- \\
-36.80 \\
-04.20 \\
-05.25 \\
-01.26 \\
\end{array}$ & $\begin{array}{c}09.60 \pm 0.40 \\
10.30 \pm 0.31 \\
09.47 \pm 0.41 \\
09.50 \pm 0.39 \\
09.53 \pm 0.40 \\
\end{array}$ & $\begin{array}{l}- \\
+07.63 \\
-01.35 \\
-01.04 \\
-00.72 \\
\end{array}$ \\
\hline CYP+ vit. E+ Zinc & \multicolumn{4}{|c|}{ GGT $\mathbf{u} / \mathbf{g}$} \\
\hline $\begin{array}{l}\text { Control } \\
\text { CYP } \\
\text { CYP+ vit. E } \\
\text { CYP + Zinc } \\
\text { CYP+ vit. E+ Zinc } \\
\end{array}$ & $\begin{array}{l}13.53 \pm 0.23 \\
19.81 \pm 0.40^{*} \\
13.08 \pm 0.21 \\
13.28 \pm 0.23 \\
13.40 \pm 0.25 \\
\end{array}$ & $\begin{array}{c}-\overline{-} \\
+46.41 \\
-03.32 \\
-01.84 \\
-00.96 \\
\end{array}$ & $\begin{array}{c}13.50 \pm 0.20 \\
12.01 \pm 0.28 \\
13.03 \pm 0.20 \\
13.20 \pm 0.23 \\
13.44 \pm 0.25 \\
\end{array}$ & $\begin{array}{c}- \\
-11.03 \\
-03.48 \\
-02.22 \\
-00.44 \\
\end{array}$ \\
\hline CYP+ vit. E+ Zinc & \multicolumn{4}{|c|}{ GSH $\mathrm{mg} / \mathrm{g}$} \\
\hline $\begin{array}{l}\text { Control } \\
\text { CYP } \\
\text { CYP+ vit. E } \\
\text { CYP + Zinc } \\
\text { CYP+ vit. E+ Zinc }\end{array}$ & $\begin{array}{l}181.85 \pm 0.81 \\
143.79 \pm 0.53 * \\
179.80 \pm 0.48 \\
180.30 \pm 0.51 \\
180.50 \pm 0.53\end{array}$ & $\begin{array}{l}- \\
-20.92 \\
-01.12 \\
-00.85 \\
-00.74\end{array}$ & $\begin{array}{c}180.81 \pm 0.51 \\
173.23 \pm 0.49 \\
175.05 \pm 0.53 \\
179.35 \pm 0.48 \\
180.63 \pm 0.53\end{array}$ & $\begin{array}{l}- \\
-04.19 \\
-03.18 \\
-0.80 \\
-0.09\end{array}$ \\
\hline
\end{tabular}

Each Value is a mean \pm SE where $n=8$.

* Statistical difference from the control: $*=$ significant at $p \leq 0.05$,

$* *=$ highly significant at $\mathrm{p} \leq 0.001$.

$\%$ of change $=[$ treatment - control $/$ control $\times 100$. 
The present data are in agreement with those reported by El-Maghraby and Taha (2012) who found that the exposure of rats to Deltamethrin (DLM) induced significant decrease in glutathione-Stransferase (GST) enzyme activity and also GSH concentration. Das et al. (2016) evaluated the protective role of zinc in attending cypermethrin induced haematological toxicity and oxidative stress in erythrocytes of male rat. They recorded reductions of glutathione content and antioxidant enzymes of rat erythrocytes. Wang et al. (2016) stated that GST is belonging to a group of multigene and multifunctional detoxification enzymes and an important condition affecting GST expression is known to be oxidative stress.

Serum GSH level as well as the liver GSH content and GST activity were significantly lower than those of the control ones after cypermethrin treatment (Tables 5 and 6). On the other hand, the present data revealed that vitamin $\mathrm{E}$ administration causes improvement in the oxidative status induced by cypermethrin causing the increase of GSH level $(+49.25 \%)$ and the activity of GGT and GST in serum were also increased $+55.89 \%$ and $+32.87 \%$, respectively in Table (6).

These results are in agreement with those reported El-Maghraby et al. (2010) who showed that administration of the chlorpyrifos and deltamethrin (DLM) caused damage in rat liver and also caused decrease in the activities of GST and DOS enzymes. Reda (2005) found that the activity of gamma glutamyl transferase (GGT) was increased and a marked reduction in each of liver glutathione (GSH) level and the activity of glutathione-s-transferase (GST) were also recorded.

Ylmaz et al. (2003) reported that selenium may have an antioxidant effect in animal tissues against cypermethrin inducing oxidative stress, but vitamin $\mathrm{E}$ alone had no beneficial effect. Moreover, Gabbianelli et al. (2004) found that the treatment with vitamins E and $\mathrm{C}$ maintained the activity of glutathione-stransferase (GST) in liver rat, while GST was significantly decreased due to chloride cadmium administration (EL-Demerdash et al., 2004).

Table (6): Effect of oral administration of Cypermethrin alone, with vitamin E, with zinc and their mixture on glutathione -s- transferase (GST), gamma glutamyl transferase (GGT) and glutathione (GSH) level in male mice serum

\begin{tabular}{|c|c|c|c|c|}
\hline \multirow[t]{2}{*}{ Groups } & \multicolumn{4}{|c|}{ GST enzyme $\mu \mathrm{mole} / \mathrm{mg}$ protein $/ \mathrm{h}$} \\
\hline & Dose period & (\%) change & Recovery period & (\%) change \\
\hline Control & $24.85 \pm 1.25$ & - & $24.45 \pm 1.05$ & - \\
\hline CYP & $31.19 \pm 1.11 *$ & +25.51 & $23.95 \pm 1.02$ & -2.04 \\
\hline CYP+ vit. E & $33.02 \pm 1.03 *$ & +32.87 & $24.01 \pm 1.03$ & -1.79 \\
\hline CYP + Zinc & $24.80 \pm 1.13$ & -0.11 & $24.13 \pm 1.05$ & -1.30 \\
\hline \multirow[t]{2}{*}{ CYP+ Vit. E+ Zinc } & $24.05 \pm 1.20$ & -3.21 & $24.30 \pm 1.02$ & -0.61 \\
\hline & \multicolumn{4}{|c|}{ GGT $\quad$ u/g } \\
\hline G Control & $261.40 \pm 1.23$ & - & $262.38 \pm 1.20$ & - \\
\hline CYP & $403.45 \pm 1.20 * *$ & +54.34 & $259.40 \pm 1.22$ & -1.13 \\
\hline CYP+ vit. E & $407.50 \pm 1.31 * *$ & +55.89 & $260.39 \pm 1.18$ & -0.75 \\
\hline CYP + Zinc & $270.13 \pm 1.29$ & +3.33 & $261.40 \pm 1.20$ & -0.37 \\
\hline \multirow[t]{2}{*}{ CYP+ vit. E+ Zinc } & $260.49 \pm 1.30$ & -0.34 & $262.09 \pm 1.30$ & -0.11 \\
\hline & \multicolumn{4}{|c|}{ GSH $\mathrm{mg} / \mathrm{g}$} \\
\hline Control & $128.09 \pm 1.20$ & - & $127.90 \pm 1.22$ & - \\
\hline CYP & $80.89 \pm 1.01 *$ & -36.84 & $126.53 \pm 1.20$ & -1.07 \\
\hline CYP+ vit. E & $191.18 \pm 1.12 *$ & +49.25 & $125.95 \pm 1.22$ & -1.52 \\
\hline CYP + Zinc & $128.01 \pm 1.20$ & -0.06 & $127.50 \pm 1.21$ & -0.31 \\
\hline CYP+ vit. E+ Zinc & $128.07 \pm 1.23$ & -0.01 & $127.80 \pm 1.20$ & -0.07 \\
\hline
\end{tabular}

Each Value is a mean \pm SE $\quad$ where $n=8$.

Statistical difference from the control: * =significant at $\mathrm{p} \leq 0.05, * *=$ highly significant at $\mathrm{p} \leq 0.001$.

$\%$ of change $=[$ treatment - control $/$ control $\times 100$.

The effect of evaluated treatments on Acetylcholinestrase (AchE) activity was investigated. Acetylcholinestrase (AchE) activity of control and other experimental groups are presented in Table (7). It is obvious from the data that cypermethrin treatment had an inhibitory effect on this enzyme extracted from brain tissue (-62.98\%) but, other treatments groups (3, 4 and 5) did not cause any significant effects compared the corresponding values of control animals. After the recovery period (2 weeks post- ceasing treatments), the data of treatments showed that they had no effect on AchE.

These results are in agreement with those obtained by El-Maghraby and Taha (2012) who found that exposuring rats to deltamethrin (DLM) induced significant decrease in GST enzyme and meanwhile acetylcholinestrase (AchE) enzyme was inhibited. It has been observed that cypermethrin induced neurotoxicity through free radical formation, reducing the antioxidant defense mechanism, and inhibiting acetylcholinesterase (AchE) (Sharma et al., 2014). 
Table (7): Effect of Cypermethrin alone, with vitamin E, with Zinc and their mixture on brain Acetylcholinesterase (ACHE) activity in male mice

\begin{tabular}{llccc}
\hline \multirow{2}{*}{ Groups administrated with } & \multicolumn{4}{c}{ AchE activity v/g } \\
\cline { 2 - 5 } & Dose period & $\mathbf{( \% )}$ change & Recovery period & (\%) change \\
\hline Control & $62.17 \pm 0.79$ & -- & $61.90 \pm 0.80$ & -- \\
CYP & $23.01 \pm 0.80 * *$ & -62.98 & $60.80 \pm 0.55$ & -1.77 \\
CYP+ vit. E & $60.90 \pm 0.85$ & -2.04 & $60.51 \pm 0.70$ & -2.24 \\
CYP + Zinc & $61.01 \pm 0.60$ & -1.86 & $61.50 \pm 0.53$ & -0.64 \\
CYP+ vit. E+ Zinc & $62.02 \pm 0.65$ & -0.24 & $61.70 \pm 0.53$ & -0.32 \\
\hline
\end{tabular}

Each Value is a mean \pm SE where $n=8$.

Statistical difference from the control: $*=$ significant at $\mathrm{p} \leq 0.05, * *=$ highly significant at $\mathrm{p} \leq 0.001$.

$\%$ of change $=[$ treatment - control $/$ control $\times 100$.

Cypermethrin was found to display AchE inhibitory activity by interacting with the anionic substrate binding site. Sharma et al. (2014) found that the administration of resveratrol (a polyphenolic phytoalexin abundantly found in grapes and red wine) increased AChE activity and ameliorated cypermethrin-induced brain damage in Wistar rats.

Rehman et al. (2006) recorded an induction in the level of lipid profile and decrease in CAT activity following the administration of deltamethrin (DLM) to albino mice for a period of 15 days at doses of 5.6 $\mathrm{mg} / \mathrm{kg}$ and $18 \mathrm{mg} / \mathrm{kg}$. Thus, significant increase in antioxidant enzyme level of experimental animals administrated with DLM+ vit. E was found as compared to those animals administrated with deltamethrin only; suggesting the protective potential effect of vitamin $\mathrm{E}$.

The decrease in AchE activity could be due to the decrease of the enzyme synthesis by the inhibitory nature of a toxicant. Accumulation of pesticides in the liver is reported to disrupt lipid metabolism and increase serum cholesterol levels (Kalender et al. 2005). The inhibition of acetylcholinestrase (AchE) acitivity in the target tissues is the most important action of cypermethrin toxicity, AchE is an enzyme that catalyzes acetylcholine and prevents its accumulation at cholinergic synapses (Uzun et al., 2009; Shah and Iqbal, 2010)

\section{CONCLUSION}

The present study was planned to evaluate sub chronic toxic effects of synthetic pyrethroids such as cypermethrin on kidney function, hormones of the thyroid, some bio-chemical parameters and antioxidant defense system. The current results demonstrated that male mice exposure to cypermethrin led to abnormal changes of certain biochemical parameters. Uric acid, creatinine and TSH were found to be significantly increased due to the treatment of cypermethrin alone. On the other hand, Triiodothyronine $\left(\mathrm{T}_{3}\right)$ and Thyroxin $\left(\mathrm{T}_{4}\right)$ were decreased. Lipid profile in serum male mice has been affected and ACHE was inhibited. Administration of zinc $(20 \mathrm{mg} / \mathrm{kg} \mathrm{b.wt} /$ day) to male mice treated with cypermethrin exhibited a significant protective role against the oxidative stress. These data suggested that zinc supplementation is a good protective agent for the mammals that may subjected to cypermethrin intoxication and therefore, results demonstrated the beneficial influences of vitamin $\mathrm{E}$ in reducing the harmful effects of cypermethrin.

\section{REFERENCES}

Abdel-Raheem, K., A. M. Abdel-Kader, S. Shaalan and H. Abou El-Zahab (1995). Effects of acute and chronic administration on amphetamine sulfate on lipid composition in serum and liver of young male albino rats. J. Egypt. Ger. Soc. Zool., 16(A): 517-536.

Abdel-Razik, R. K. (2018). Effects of Nigella sativa oil on the imidacloprid induced toxicity in male albino mice. Alex. J. Agric. Sci., 63(4): 239-250.

Allian, C. C., L. S. Poon, C. S. Chan, W. Richmonal and P. C. Fu (1974). Enzymatic determination of total serum cholesterol. J. Clin. Chem., 20(4): 470-476.

Aman, S., Y. Bhuvnesh, R. Shipra and Y. Baljeet (2018). Cypermethrin Toxicity: A Review. J. Forensic Sci. Criminal Inves., 9(4): 555767.

DOI:10.19080/JFSCI.2018.09.555767.

Asami, T., M. Wada and M. Uchiyama (2001). Plasma free fatty acids in neonates with congenital hypothradism. Thyroid, 11(1): 81-84.

Assayed, M. E., A. A. Khalaf and H. A. Salem (2010a). Protective effects of garlic extract and vitamin $\mathrm{C}$ against in vivo cypermethrininduced cytogenetic damage in rat bonemarrow, Mutat. Res, 702; 1-7.

Assayed, M.E., A. A. Khalaf and H. A. Salem (2010b). Protective effects of garlic extract and vitamin $\mathrm{C}$ against in vivo cypermethrininduced tetratogenic effects in rat offspring. Food and Chemical Toxicology, 48: 31533158.

Atessahin, A., S. Yilmaz, U. Karahan, I. Pirincci and B. Tasdemir (2005). The effects of vitamin $\mathrm{E}$ and selenium on cypermethrin-induced oxidative stress in rats. Turk. J. Vet. Anim. Sci., 29: 385-391. 
Bateman, D. N. (2000). Management of pyrethroid exposure. J. Toxicol. Clin. Toxicol., 38: 107-109.

Burstein, M. (1970). High-density lipoprotein cholesterol. Lipid Res., 11: 583-585.

Das, T., A. Pradhan, A. Paramanik and S. M. Choudhury (2016). Ameliorative role of zinc on cypermethrin induced changes in haematological parameters and oxidative stress biomarkers in rat erythrocytes. Toxicol. Environ. Health Sci., 8(3): 234246.

Eissa, F. I. and N. A. Zidan (2010). Haematological, biochemical and histopathological alterations induced by abamectin and Bacillus thuringiensis in male albino rats. Australian J. Basic Appl. Sci., 3(3): 24972505.

El-Demerdash, F. M., M. I. Yousef, F. S. Kedwany and H. H. Baghdadi (2004). Cadmiuminduced changes in lipid peroxidation, blood haematology, biochemical parameters and semen quality of male rats: Protective role of vitamin $E$ and $\beta$-carotene. Food Chemical Toxicol., 42: 1563-1571.

Ellman, G. L., K. D. Countery, V. J. R. Anders and R. M. Featherstone, (1961). A new rapid colorimetric determination of acetylcholineesterase activity. Biochem. Pharmacol., 7: 88-95.

El-Maghraby, S and H. A. Taha (2012). Melioratory effects of vitamin $\mathrm{E}$ against biochemical toxicity induced by deltamethrin in male rats. J. Arab. Soc. Med. Res., 7: 92-96.

El-Maghraby, S., H. A. Taha and N. Hassan (2010). Effects of Anthum graveolens L. extract on biochemical and histopathological alteration of deltamethrin in rats. J. Bioanal. Biomed., 2(1): 8-12.

EL-Sayed, N. M. (2001). Prophylactic and therapeutic roles of $\mathrm{A}$ and $\mathrm{E}$ on creatine and creatinine levels in both serum and cardiac muscle in irradiated rats. J. Egypt. Ger. Soc. Zool., 34(A): 21-29.

Evans, P. and B. Halliwell (2001). Micronutients: oxidant/antioxidant status. Br. J. Nutr., 85(2):67-74.

Finch, J. M., T. G.Osimitz, K. L. Gabriel, T. Martin, W. J. Henderson, C. C. Capen, W. J. Bulter and B. G. Lacke (2006). A mode of action for induction of thyroid gland tumors by pyrethrins in the rat. Toxicol. Appl. Pharmacol., 214(3): 253-262.

Fossati, D. and L. Prencipe (1982). The determination of triglycerides using enzymatic method. J. Clin. Chem., 28: 2077-2082.

Friedewals, W. T., R. I. Levy and D. C. Frierickson (1972). Estimation of the concentration of low density lipoprotein cholesterol in plasma without use of the preparative ultracentrifuge. Clin. Chem., 18: 499-507.
Gabbianelli, R., C. Nausti, G. Falcioni and F. Cantalamessa (2004). Lymphocyte DNA damage in rats exposed to pyrethroids: effect of supplementation with vitamins $\mathrm{E}$ and C. Toxicol., 203(1/3): 17-26.

Ghazouani, L., A. Fericini, A. Mufti, M. Tir, T. Buaziz, H. B. Mansour and K. Mnufgui (2020). Toxic effect of alpha cypermethrin, an environmental pollutant on myocardial tissue in male Wistar rats. Environ. Sci. Pollu. Res., 27: 5709-5717.

Girgis, R. B., F. I. Khamis, K. I. Abdel-Fattah and N. M. Abu-Zeid (2000). Protection role of serotonin against deprivation and gamma radiation disorders on hormonal levels of the pituitary-thyroid axis in rat plasma. J. Egypt. Ger. Soc. Zool., 31(A): 249-271.

Gumulee, J.; M. Masarik and S. Krizkova (2011). Insight to physiology and pathology of zinc (II) ions and their actions in breast and prostate carcinoma. Curr. Med. Chem., 18: 5041-5051.

Habig, W. H., M. J. Patst and W. B. Jakoby (1974). Glutathione s-transferases, the first enzymatic step in mercapturic acid formation. J. Biol. Chem., 249: 7130-7139.

Herman, E. H. and V. J. Ferrans (1983). Influence of vitamin $\mathrm{E}$ and ICRF-187 on chronic doxorubicin cardiotoxicity in miniature swine. Lab. Invest., 49: 69-77.

Hine, J. and G. B. Wetherill (1975). A programmed text in statistics. Book three, t-test and $\mathrm{X}^{2}$ goodness of fit. Chapman and Hall, London.

Jalili, T., A. Khaki, Z. Ghanbari, A. M. Imami and F. Hatefi (2014). A study of the therapeutic effects of vitamin $\mathrm{E}$ on testicular tissue damage caused by fluoxetine. Crescent J. Med. Biol. Sci., 1: 37-41.

Jee, J. H., F. Masroor and J. C. Kang (2005). Responses of Cypermethrin-induced stress in haematological parameters of Korean rock fish. Sebastesschlegeli Aqua. Res., 36: 898-905.

Kalender, S., A. Ogutcu, M. Uzunhisarcikli, A. Durak, D. Ulusoy and Y. Kalender (2005). Diazinon-induced hepatotoxicity and protective effect of vitamin $\mathrm{E}$ on some biochemical indices and ultrastructural changes.Toxicol., 211: 197-206.

Kang, Y. J. and Z. Zhou (2005). Zinc prevention and treatment of alcoholic liver disease. Mol. Aspects. Med., 26: 391-404.

Kazi, T. G., N. F. Kolachi, H. I. Afridi, N. G. Kazi, S. Naeemullah and S. S. Arain (2012): Effects of Mineral Supplementation on Liver Cirrhotic/Cancer Male Patients. Biol. Trace Elem. Res., 150: 81-90.

Knight, J., S. Anderson and M. R. James (1972). Chemical basis of the sulphophosphovanillin reaction for estimating total serum lipids. J. Clin. Chem., 18(3): 199-202. 
Reda, Laila A. (2005). Evaluation of toxicity of orally administrated cadmium, cypermethrin and their mixtures based on some enzymes markers in male mice. SCVMJ, 8(1): 1-12.

Lowry, O. H., N. J. Rosebrough, A. L. Farr and R. J. Randall (1951). Protein measurements with the folin phenol reagent. J. Biol. Chem., 139: 269-275.

Mitchell, R. J. (1973). Improved method for specific determination of creatinine in serum and urine. Clin. Chem., 19: 408-410.

Morimoto K. and K.A. Inouye (1997) . Sensitive enzyme immunoassay of human Thyroid Stimulating hormone (TSH) using bispecific $\mathrm{F}$ (ab)2 fragments recognizing polymerized alkaline phosphatase an TSH ., J. Immunol .Methods, 205(1): 81-90

Morgenstern, S., R.V. Flor, J. H. Kaufman and B. Klein (1966). The automated determination of serum urine acid. Clin. Chem., 12: 748766.

Nazirogln, M., M. Cay, B. Stundag, M. Aksakal and H.Yekeler (1999). Protective effects of vitamin $\mathrm{E}$ on Carbon tetrachloride-induced liver damage in rats. Cell Biochem. Funct., 17: 253-259.

Prasad, A. S. (2008). Clinical immunological, antiinflammatory and antioxidant roles of zinc. Exp. Geront., 43: 370-377.

Pucci, E., L. Chiovato and A. Pinchera (2000). Thyroid and lipid metabolism. Int. J. Obes. Relat. Metab. Disord., 24(2): 109-112.

Rehman, H., M. Ali, F. Atif, K. Bhatia and S. Raisuddin (2006). The modulatory effect of deltamethrin on antoxidants in mice. Clin. Chim. Acta., 369: 61-65.

Richardson, R. J. and S. D. Murphy (1975). Effects of glutathione depletion on tissue deposition of methylmercury in rats. Toxicol. Appl. Pharmacol., 31: 505-519.

Saeed, R. M. A. and A. M. EL-Gendy (2000). Agerelated changes of lipid peroxidation and anti-oxidants in different organs of rats and the effect of combined treatment with vitamin C and E. Egypt. J. Zool., 35: 209222.

Sangha, G. K., K. Kaur and K. S. Khera (2013). Cypermethrin induced pathological and biochemical changes in reproductive organs of female rats. J. Environ. Biol., 34: 99-105.

Shafer, T. J. and D. A. Meyer (2004). Effects of pyrethroids on voltage-sensitive calcium channels: a critical evaluation of strengths, weaknesses, data needs and relationship to assessment of cumulative neurotoxicity. Toxicol. Appl. Pharmocol., 196: 303-318.
Shah, M. D and Iqbal, M. (2010). Diazinon-induced oxidative stress and renal dysfunction in rats. Food chem Toxicol., 48: 3345-3353.

Sharma, P., S. Firdous and R. Singh (2014). Neurotoxic effect of cypermethrin and protective of resveratrol in Wistar rats. Int. J. Nutri. Pharm. Neuro. Dis., 4(2): 104-111.

Thakur.C, T.C .Saikia and R.N.S. Yadav (1997). Total Serum Levels of triiodothyronine $\left(\mathrm{T}_{3}\right)$, Thyroxine $\left(\mathrm{T}_{4}\right)$ and Thyrotropine (TSH) in school going children of Dibrugarh district: an endemic goiter region of Assam. Indain J. physiol . pharmacol., 41(2): 167-170

Uzun, F.G., S. Kalender, D. Durak, F. Demir and Y. Kalender (2009). Malathion-induced testicular toxicity in male rats and the protective effect of vitamin C and E. Food chem. Toxicol., 47: 1903-1908.

Walmsley, R.N. and G. H. White (1994). A guide to diagnositic clinical chemistry. $3^{\text {rd }}$ ed., Blackwerd Scientific Publication, London.

Wang, S., N. Shi, Z. Ji and G. Pinna (2002). Effects of pyrethroids on the concentrations of thyroid hormones in the rat serum and brain. Zhonghua Lao Dong Wei Shen Zhi Ye Bing Za Zhi., 20(3): 173-176.

Wang, X., M. A. Martinez, M. Dai, D. Chen, I. Ares, A. Romero, V. Castellano, M. Martinez, J. L. Rodriguez, M. R. Martinez,-Larranaga, A. Anadon and Z. Yuanz (2016). Permethrin-induced oxidative stress and toxicity and metabolism: A review. Environ. Res., 149: 86-104.

Yavuz, T., N. Delibas, B. Yilidrim, L. Altuntas, O. Candir and A. Cora (2004). Vascular wall damage in rats induced by methidathion and ameliorating effect of vitamins $\mathrm{E}$ and $\mathrm{C}$. Arch. Toxicol., 78: 655-659.

Ylmaz, S., A. Atessahin and I. Karahan (2003). The effect of vitamin E, selenium and vitamin $\mathrm{E}$ plus selenium on glutathione levels and glucose-6-phosphate dehydrogenase activities in Cypermethrin administered rats. Pendik.Veterine. Mikrobiyoloji Dergisi., 34(1/2): 57-60.

Young, D. (1990). Effect of drugs on clinical laboratory tests. AACC press, Washinghton D. C., USA.

Yousef, M. I., T. I. Awad and E. H. Mohamed (2006). Deltamethrin-induced oxidative damage and biochemical alterations in rat and its attenuation by vitamin E. Toxicol., 227: 240-247.

Yousef, M. (2010). Vitamin E modulates reproductive toxicity of pyrethroid lambdacyhalothrin in male rabbits .Food and Chem. Toxicol., 48: 1152-1159. 


\section{التأثيرات السامة لتناول السيبرميثرين وفيتامين E والزنك ومخاليطهم على نشاط هرمون الغدة

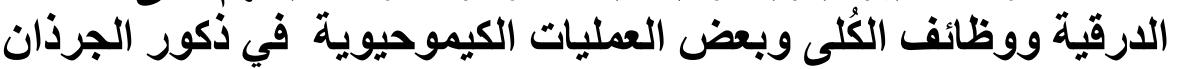

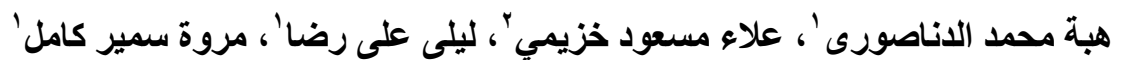

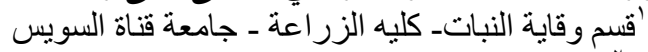

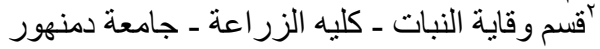

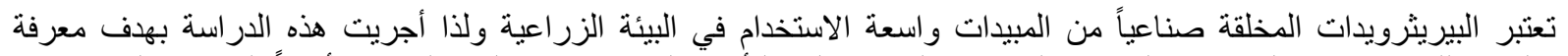

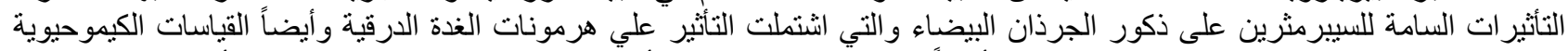

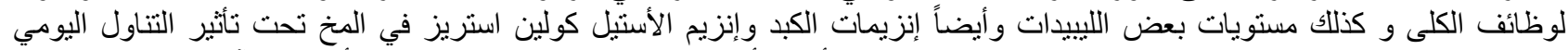

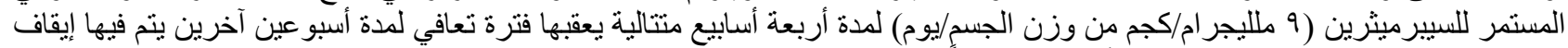

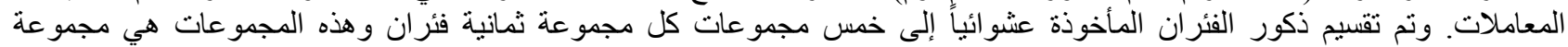

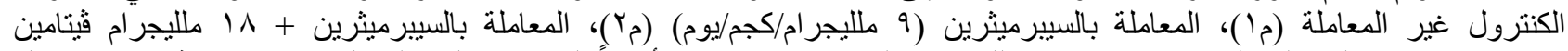

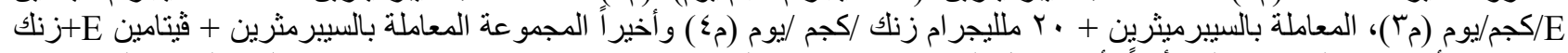

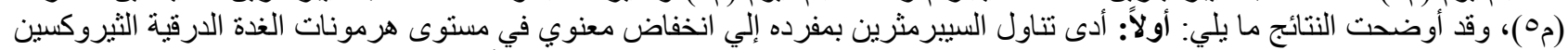

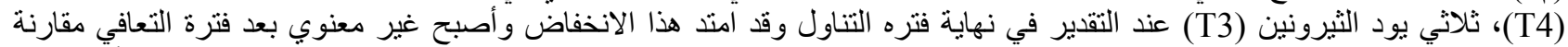

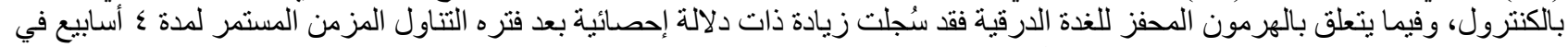

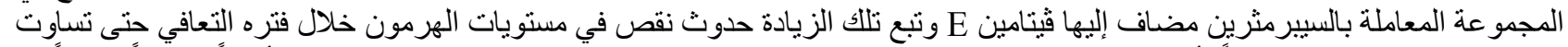

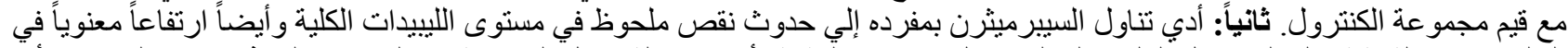

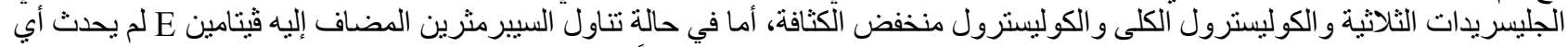

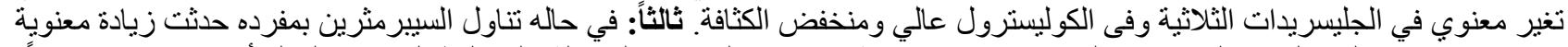

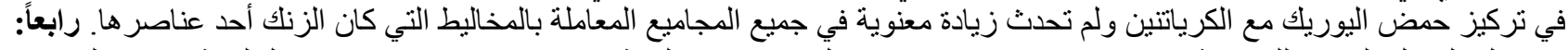

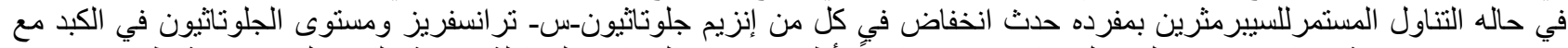

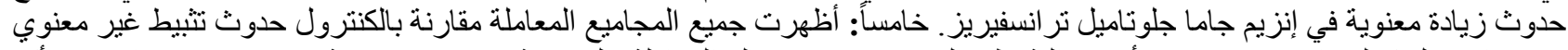

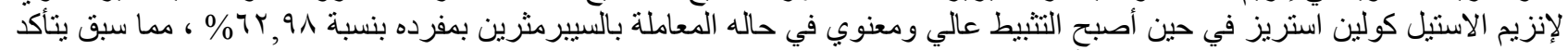

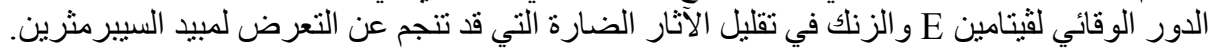

